\author{
Michat Sajewicz \\ Kierownik Zakładu Białorutenistyki UMCS \\ Dyrektor Instytutu Filologii Stowiańskiej
}

\title{
Białorutenistyka w UMCS w Lublinie
}

Białorutenistyka w UMCS w Lublinie również obchodzi swój Jubileusz - 20 rocznicę powstania studiów białorutenistycznych w naszej Uczelni. W 1993 uruchomiono w UMCS w ramach kierunku filologia specjalność filologia białoruska. W 2002 roku powołano w UMCS slawistykę i od tej pory kształcenie białorutenistów odbywa się w ramach studiów slawistycznych. Studenci poznają, w różnym zakresie, kilka języków słowiańskich - język białoruski, język bułgarski, język czeski i język ukraiński.

Obecnie Zakład Białorutenistyki Instytutu Filologii Słowiańskiej zatrudnia 7 pracowników: 3 pracowników samodzielnych (prof. dr hab. Siarhei Kavaliou, dr hab. Michał Sajewicz, prof. nadzw. UMCS, dr hab. Zoja Melnikava, prof. nadzw. UMCS), 3 doktorów (dr Yadviha Kazlouskaya-Doda, dr Natalia Rusetskaya, dr Agnieszka Goral) i jednego magistra (mgr Darya Kiyko).

W ostatnim okresie prof. S. Kavaliou uzyskał tytuł profesora, uruchomiono również procedurę nadania tytułu profesora dr hab. M. Sajewiczowi, prof. nadzw. UMCS. Dwóch pracowników uzyskało stopień naukowy doktora nauk humanistycznych (dr N. Rusetskaya - promotor - prof. W. Kowalczyk, dr A. Goral - promotor - prof. M. Sajewicz). Stopień naukowy doktora nauk humanistycznych uzyskały ponadto następujący doktoranci, przypisani do Zakładu Białorutenistyki: dr M. Denda - promotor prof. M. Sajewicz, dr H. Karpovich - promotor prof. S. Kavaliou, dr T. Netbayeva - promotor prof. S. Kavaliov. Kilka przewodów doktorskich jest w trakcie realizacji: mgr P. Dawidowski - promotor prof. M. Sajewicz, T. Kuzyk - promotor S. Kavaliov. 
Zakład Białorutenistyki IFS realizuje następujące tematy badawcze:

1. Gwary polsko-białorusko-ukraińskiego pogranicza językowego (prof. M. Sajewicz, dr Y. Kazlouskaya-Doda);

2. Antroponimia pogranicza polsko-białorusko-ukraińskiego (prof. M. Sajewicz);

3. Derywacja rzeczowników w gwarach białoruskich Białostocczyzny (prof. M. Sajewicz);

4. Morfologia, słowotwórstwo i leksyka współczesnego białoruskiego języka literackiego (prof. M. Sajewicz, dr Y. Kazlouskaya-Doda, dr A. Goral, mgr D. Kiyko);

5. Białorusko-polskie związki literackie obecnie i w przeszłości (prof. S. Kavaliou, prof. Z. Melnikava, dr N. Rusetskaya);

6. Współczesna dramaturgia białoruska (prof. S. Kavaliov. dr N. Rusetskaya);

7. Współczesna literatura białoruska (prof. S. Kavaliou, prof. Z. Melnikava, dr N. Rusetskaya);

Efektem realizacji wymienionych tematów badawczych były monografie oraz liczne artykuły naukowe pracowników Zakładu Białorutenistyki. Powstały dwie monografie o słowotwórstwie białoruskim (prof. M. Sajewicz, dr A. Goral), monografia dotycząca antroponimii Białostocczyzny prof. M. Sajewicz, dwie monografie poświęcone literaturze Wielkiego Księstwa Litewskiego (prof. S. Kavaliou), monografia poświęcona twórczości F. U. Radziwiłłowej) - dr N. Rusetskaya).

W latach 1993-2013 pracownicy Zakładu Białorutenistyki opublikowali w kraju i za granicą 35 pozycji książkowych (monografie, zbiorki artykułów, wydawnictwa ciągłe, podręczniki, literatura piękna):

1. Studia z jezykoznawstwa słowiańskiego, „Rozprawy Slawistyczne” 10, red. M. Łesiów, M. Sajewicz, Wydawnictwo UMCS, Lublin 1995, ss. 406 .

2. Jan Adamowski, Jerzy Bartmiński, Feliks Czyżewski, Jan Górak, Stanisława Niebrzegowska, Halina Pelcowa, Janina Pitera, Michał Sajewicz, Maszynopis: Kwestionariusz do Atlasu Etnolingwistycznego Pobu$\dot{z} a$, Lublin 1997 (do użytku wewnętrznego).

3. Materiały Międzynarodowej Konferencji Naukowej „Droga ku wzajemności”, „Acta Albaruthenica” 4, red. A. Barszczewski, M. Sajewicz, Mińsk 2004, ss. 300.

4. Michał Sajewicz, Derywacja sufiksalna osobowych nazw subiektów w nadnarwiańskich gwarach białoruskich Białostocczyzny. Deverbativa, deadiectiva, Wydawnictwo UMCS, Lublin 2002, ss. 521.

5. Н. Русецкая, Два бяссонні. Вершы і пераклады, Мінск 2004, сс. 80. 
6. S. Kowalow, Zmęczony diabeł. Dramaty, przekład z jęz. biał.: T. Giedz, B. Siwek, M. Sajewicz, Wydawnictwo UMCS, Lublin 2004, ss. 267.

7. С. Кавалёў, Стомлены д'ябал. П'есы, Мінск 2004, сс. 191.

8. С. Кавалёў, Навука кахання. П'есы, Мінск 2005, сс. 191.

9. С. Кавалёў, Літаратура Беларусі позняга рэнесансу. Жанры, творы, асобыл, Мінск 2005, сс. 199.

10. С. Кавалёў, Гісторыя беларускай літаратуры: другая палова XVI cm. Курс лекиьй, Мінск 2005, сс. 110.

11. Вар'ят і манашка. Польская драматургія $X X \mathrm{~cm}$. Зборнік, укл. С. Кавалёў, Мінск 2006, сс. 210.

12. Н. Русецкая, Сямейная муза. Паэзія Франиішкі Уршулі Радзівіл, Мінск 2007, сс. 212.

13. „Studia Białorutenistyczne” 1, red. R. Radzik, M. Sajewicz, Wydawnictwo UMCS, Lublin 2007, ss. 420.

14. Феномен пагранічча. Польская, украінская $i$ беларуская літаратура-упльввы $і$ ўзаемадзеянне, рэд. С. Кавалёӱ, І. Набытовіч, Мінск 2008, cc. 400.

15. „Studia Białorutenistyczne” 2, red. R. Radzik, M. Sajewicz, Wydawnictwo UMCS, Lublin 2008, ss. 412.

16. „Studia Białorutenistyczne” 3, red. R. Radzik, M. Sajewicz, Wydawnictwo UMCS, Lublin 2009, ss. 400.

17. Паміж Беларуссю і Польшчай. Драматургія Сяргея Кавалёва // Pomiędzy Białorusia a Polska. Dramaturgia Siarhieja Kawalowa, прадмова: Л. Грамыка, І. Лапо, рэд. А. Ліопа, А. Баровец, Мінск 2009, cc. 435 .

18. Беларуская літаратура. Дапаможнік для 11 класа, рэд. З. П. Мельнікава, Г. М. Ішчанка, Мінск 2009, сс. 304.

19. „Studia Białorutenistyczne” 4, red. R. Radzik, M. Sajewicz, Wydawnictwo UMCS, Lublin 2010, ss. 386.

20. Białoruś: przeszłość i teraźniejszość - kultura, literatura, język, red. R. Radzik, M. Sajewicz, Wydawnictwo UMCS, Lublin 2010, ss. 255.

21. Polsko-białoruskie zwiazki kulturowe, literackie i językowe, red. S. Kawalou, R. Radzik, M. Sajewicz, Wydawnictwo UMCS, Lublin 2010, ss. 411.

22. С. Кавалёў, Шматмойная паэзія Вялікага Княства Літоўскага эпохі Рэнесансу, Мінск 2010, сс. 376.

23. Гісторыя беларускай літаратуры XI-XIX стагоддзяў, у 2 т., т. 1: Даўняя літаратура: XI - першая палова XVIII cm., рэд. В. Чамярыцкі, Мінск 2006, сс. 910 (С. Кавалёў у сааўтарстве - раздзелы: На парозе Новага часу, Паэзія, Андрэй Рьмша, Гальяш Пельгрымоускі, Ян Пратасовіч, Драматургія). Наступныя перавыданні: 2008, 2010. 
24. С. Кавалёў, Літаратура Вялікага Княства Літойскага XVI-naчатку XVII стст.: Феномен культурнага памежжа, Мінск 2011, cc. 344 .

25. Radziwiłłowa F. U. Album nieświeski- Радзівіл Ф. У., Нясвіжскі альбом. Зборнік любойнай лірыкі, wybór S. Kawalou, tłumacz. N. Rusiecka, Мінск 2011, ss. 141.

26. Dziedzictwo kulturowe Wielkiego Księstwa Litewskiego, red. S. Kawalou, M. Kojder, Wydawnictwo UMCS, Lublin 2011, ss. 224.

27. С. Кавалёў, Сёстры Псіхеі. П'есы, Мінск 2011, сс. 220.

28. З. Мельнікава, Метадалогія літаратуразнаўства, БрДУ імя А. С. Пушкіна, Брэст 2011, сс. 180.

29. „Studia Białorutenistyczne” 5, red. R. Radzik, M. Sajewicz, Wydawnictwo UMCS, Lublin 2011, ss. 487.

30. „Studia Białorutenistyczne” 6, red. M. Korzeniowski, S. Kawalou, M. Sajewicz, Wydawnictwo UMCS, Lublin 2012, ss. 440.

31. Г. Карповіч, Кніжна-эпіграматычная паэзія Вялікага Княства Літойскага XVI cm. ў кантэксце антычнай традыцыи, рэд. С. Кавалёў, Мінск 2012, сс. 359.

32. Т. Нетбаева, Чалавек $і$ гісторыя ў беларускіх мясцовых хроніках XVII-XVIII cmcm., рэд. С. Кавалёӱ, Мінск 2012, сс. 280.

33. M. Sajewicz, Nazwiska patronimiczne $z$ formantem $-u k w$ powiecie hajnowskim na Białostocczyźnie na tle ogólnopolskim, Wydawnictwo UMCS, Lublin 2013, ss. 725.

34. С. Кавалёў, Крыьвічкі апокрыц. П'есьь, Białoruskie Stowarzyszenie Literackie „Białowieża”, Białystok 2013, ss. 159.

35. С. Кавалёў, Пачвара ў рэліктавым лесе. Літаратура. Тэатр. Крытылка, Мінск 2013, сс. 234.

Wkrótce ukaże się drukiem:

1. A. Goral, Derywacja sufiksalna nazw subiektów czynności we wspótczesnym języku białoruskim. Dewerbalne i desubstantywne formacje agentywne. Wydawnictwo UMCS, Lublin 2013.

W latach 1993-2013 pracownicy Zakładu Białorutenistyki opublikowali w wydawnictwach krajowych i zagranicznych około 600 artykułów naukowych, popularno-naukowych recenzji, sprawozdań z konferencji, not o książkach i publikacji okolicznościowych.

Liczne artykuły naukowe, recenzje, sprawozdania z konferencji ukazały się w lubelskich „Studiach Białorutenistycznych”. Jest to rocznik wydawany początkowo pod redakcją R. Radzika i M. Sajewicza, a obecnie M. Korzeniowskiego, S. Kawalowa i M. Sajewicza. Do tej pory ukazało się 6 numerów tego wydawnictwa. Do druku złożono 7 numer rocznika. „Studia Białorutenistyczne" znajdują się na liście czasopism punktowanych MNiSzW. 
Pracownicy Zakładu Białorutenistyki aktywnie uczestniczą w krajowych i zagranicznych konferencjach naukowych. Tylko w ciągu 4 ostatnich lat wygłosili 75 referatów na konferencjach naukowych organizowanych w takich krajach, jak Polska, Białoruś, Litwa, Ukraina, Rosja, Estonia, Łotwa, Słowacja, Czechy, Serbia, Wielka Brytania, Niemcy, Turcja i Cypr.

Na szczególną uwagę zasługuje udział pracowników Zakładu Białorutenistyki (7 osób) w V Kongresie Międzynarodowej Asocjacji Białorutenistów, który odbył się w Mińsku w 2010 roku. Pracownicy Zakładu uczestniczyli również w kolejnych edycjach $(2008,2009,2010,2011,2012)$ konferencji Polsko-białoruskie zwiazki kulturowe, literackie i językowe. W roku 2009 i 2011 organizatorem konferencji był Białoruski Uniwersytet Państwowy w Mińsku, a w roku 2008, 2010, 2012 - Zakład Białorutenistyki IFS UMCS. Współorganizatorami 3 ostatnich konferencji lubelskich z cyklu Polsko-biatoruskie zwiazki kulturowe, literackie i językowe były Zakład Makrostruktur Społecznych Instytutu Socjologii UMCS, Zakład Historii Krajów Europy Wschodniej Instytutu Historii UMCS, Katedra Białorutenistki Uniwersytetu Warszawskiego, Polskie Towarzystwo Białorutenistyczne, Instytut Polski w Mińsku i Podlaska Fundacja Wspierania Talentów.

Rezultaty badań naukowych pracowników Zakładu Białorutenistyki były także prezentowane na zebraniach Zakładu. Przyjęto zasadę, że każdy doktorant i młodszy pracownik naukowy przynajmniej dwukrotnie przedstawia wyniki swoich badań na otwartych zebraniach naukowych Zakładu. Referaty wygłosili m.in. A. Borowiec, M. Denda, Y. Kazlouskaya-Doda, P. Dawidowski, T. Netbayeva, H. Karpowich, T. Kuzyk, N. Rusetskaya, D. Kiyko, N. Mazurava.

W celu wygłoszenia referatu zapraszano również badaczy kultury, literatury i języka białoruskiego spoza Zakładu Białorutenistyki, najczęściej z Białorusi. Niektóre odczyty były organizowane wspólnie przez Zakład Białorutenistyki i Koło Naukowe „Albaruthenica”. Lileja Plygavka z Wilna wygłosiła referat dla pracowników i studentów o sytuacji językowej na Wileńszczyźnie (2009). Gun-Britt Kohler (Oldenburg) przedstawiła referat pt. „Literatura a teoria Pola” (2010). Anatol Iwaszczenko (Mińsk) mówił o poezji Alesia Razanowa (2010). Walery Jaworowski (Mińsk) i Halina Rarot (Instytutu Filozofii UMCS) przybliżyli filozofię białoruską (2010).

Odbywały się także spotkania z twórcami literatury i teatru białoruskiego. Były organizowane przede wszystkim z myślą o studentach zainteresowanych kulturą białoruską. W 2009 roku odbyły się spotkania z poetkami Iryną Dorofiejczuk, Haliną Twaranowicz i Taccianą Niedbaj. W 2010 roku zorganizowano spotkanie z pisarzem białoruskim Borysem Piatrowiczem (prezentacja książki „Płaszcza”), a także spotkanie z zespołem redakcyjnym 
czasopisma „Dziejasłou”. W tym samym roku odbyło się także spotkanie z pisarką Natalką Babiną, autorką książki „Miasto ryb”, i białoruskim dramaturgiem S. Kawalowem, który wygłosił odczyt na temat współczesnego teatru białoruskiego.

W 2011 roku odbyło się spotkanie z twórcami teatru białoruskiego Mikołajem Chalezinem i Natalią Koladą. W tym samym roku dr hab. Iryna Lappo (IFP UMCS) dokonała prezentacji tomu wierszy F. U. Radziwiłłowej (w tłumaczeniu dr N. Rusieckiej). Dużym zainteresowaniem cieszyły się wieczory poetyckie z udziałem Tacciany Niedbaj i Iryny Dorofiejczuk.

W 2012 roku odbyło się spotkanie z Wolhą Baburyną, która mówiła o wycinankach białoruskich. W tym samym roku gościem Zakładu Białorutenistyki były Tacciana Biełanohaja, autorka poezji śpiewnej, i poetka Wolha Hapiejewa.

Interesująca było również wystawa fotografii o historii i dniu współczesnym Białorusi. Zdjęcia wykonał i prelekcję poprowadził Paweł Dawidowski.

Zakład Białorutenistyki UMCS blisko współpracuje z Katedrą Białorutenistyki Uniwersytetu Warszawskiego. Od wielu lat są wspólnie organizowane konferencje naukowe z cyklu Polsko-białoruskie zwiazki kulturowe, literackie i języków. Cenna jest także współpraca Zakładu Białorutenistyki z Białoruskimi Uniwersytetami Państwowymi w Mińsku i Brześciu. Współpraca dotyczy w szczególności:

1. Wymiany studentów - studia semestralne i praktyki językowo-kulturowe

2. Organizacji wspólnych konferencji slawistycznych, m.in. konferencji Polsko-białoruskie zwiazki kulturowe, literackie i jezykowe

3. Działalności wydawniczej

Dobrze rozwija się także współpraca z białorutenistami angielskimi (Arnold McMillin), węgierskimi (András Zoltán), niemieckim (Gun-Britt Kohler), austriackimi (Hermann Bieder) i litewskimi (Lileja Plygavka).

Bliskie kontakty Zakład Białorutenistyki utrzymuje z Międzynarodową Asocjacją Białorutenistów, w szczególności w zakresie organizacji konferencji i działalności wydawniczej.

O aktywności organizacyjnej pracowników Zakładu Białorutenistyki świadczy ich udział $\mathrm{w}$ licznych organizacjach krajowych i międzynarodowych:

1. Prof. Michał Sajewicz:

- Członek Prezydium Międzynarodowej Asocjacji Białorutenistów;

- Przewodniczacy Zarządu Głównego Polskiego Towarzystwa Białorutenistycznego.

- Członek Lubelskiego Towarzystwa Naukowego; 
- Członek Komisji Etnolingwistycznej w Komitecie Językoznawstwa Polskiej Akademii Nauk;

- Członek ZAIKS-u.

2. Prof. Siarhei Kavaliou:

- Członek Prezydium Międzynarodowej Asocjacji Białorutenistów;

- Członek Zarządu Głównego Polskiego Towarzystwa Białorutenistycznego;

- Członek Związku Pisarzy Białorusi.

3. mgr Agnieszka Goral:

- sekretarz ZG Polskiego Towarzystwa Białorutenistycznego.

Pracownicy Zakładu są również (lub byli) członkami Kolegiów Redakcyjnych następujących wydawnictw:

1. Prof. Michał Sajewicz:

- „Studia Białorutenistyczne” - przewodniczaccy Kolegium Redakcyjnego;

- „Rozprawy Slawistyczne” - członek Kolegium Redakcyjnego;

- „Etnolingwistyka” - członek Kolegium Redakcyjnego;

- „Facta Simonidis” - członek Rady Programowej;

- „Wiesnik” Białoruskiego Uniwersytetu Państwowego w Mińsku, seria 4 - członek Kolegium Redakcyjnego

2. Prof. Siarhei Kavaliou:

- „Studia Białorutenistyczne” - członek Kolegium Redakcyjnego

- „Alba Ruthenica” - członek Kolegium Redakcyjnego

3. Prof. Zoya Melnikava jest członkiem kolegiów redakcyjnych kilku wydawnictw ciągłych ukazujących się na Białorusi

4. Mgr Agnieszka Goral:

- sekretarz Komitetu Redakcyjnego rocznika „Studia Białorutenistyczne" (Lublin)

Reasumując, można stwierdzić, że w ciągu 20 ostatnich lat Lublin stał się znaczącym ośrodkiem badań białorutenistycznych. Badania nad kulturą, literaturą i językiem białoruskim są prowadzone głównie przez pracowników Zakładu Białorutenistyki Instytutu Filologii Słowiańskiej UMCS. Uczestniczą w nich także pracownicy innych jednostek tej uczelni (Instytut Filologii Polskiej, Instytut Historii, Instytut Socjologii, Instytut Filozofii). Ponadto badania białorutenistyczne, głównie w zakresie literatury, są prowadzone również w Instytucie Filologii Słowiańskiej KUL. 


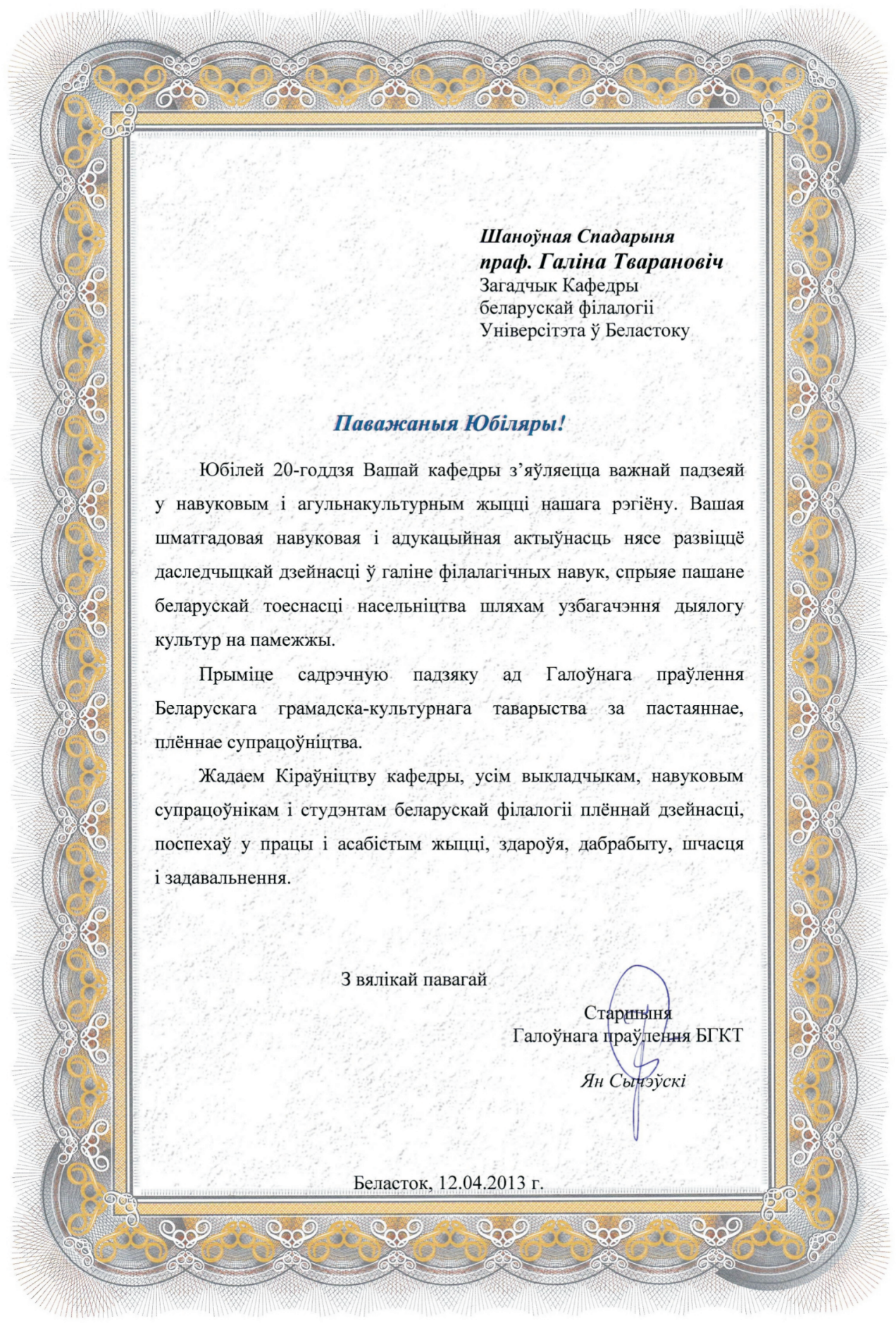


Гайнаўка, 12.04.2013 2.

Комплекс школ

3 дадатковым навучаннем

беларускай мовы ў Гайнауццы

Спадарыні Прафесар

Галіне Тварановіч

Кіраўніку беларускай філалогіi

ва Універсітэце ў Беластоку

\section{Шаноўная Спадарыня Прафесар,}

прыміце самыя шчырыя віншаванні 3 нагоды Вашага знамянальнага юбілею. На працягу 20-ці гадоў беларуская філалогія ў Беластоку дала выдатную адукацыю многім маладым людзям, захоўваючы пашану да нашай роднай мовы, літаратуры, беларускіх традыцый $і$ абрадаў.У Вас значныя поспехі таксама $\check{y}$ навуковай $i$ выдавецкай дзейнасці. Гэта добры прыклад для уссіх беларусаў. У гэтым вялікая заслуга кіраўніцтва, выкладчыкаў $і$ студэнтаў кафедры.

Жадаем Вам творчых поспехаў і плёну у працы, натхнення і аптымізму, моцнага здароўя $і$ асабістага шчасця.

3 вялікай павагай,

Дырэкцыя, Настаўнікі і Вучні

Белгімназіі і Белліцэя у Гайнауццы 
Комплекс школ 3 дадатковым навучаннем беларускай мовы імя Яраслава Кастыцэвіча ў Бельску Падляшскім

\section{Віншаванні}

Дырэкцыя, настаўнікі і вучні

Комплексу школ 3 дадатковым навучаннем беларускай мовы імя Яраслава Кастыцэвіча

ў Бельску Падляшскім шчыра і сардэчна віншуюць Кафедру беларускай філалогіi Універсітэта ў Беластоку з юбілеем дваццацігоддзя.

Жадаем Вам многа поспехаў і асабістага задавальнення ў далейшай працы на ніве беларускасці ў карысць беларусаў у Полышы, беларускай мовы, літаратуры і культуры.

ZESPOZ SZKOZ odatkową Nauka Jezyka Bialorus

7-100 Bielsk Podlaski, ul. Poniatowskiego 9

7. 730.055 .

REG.051971356, NiP 543-19-62-315

Дырэктар Комплексу школ

3 ДНБМ у Бельску Падляшскім

DYREKTOR ZESPOEU SZKÓL mgrEugenia Wasiluk 